\title{
COMPARISON OF THE SIGNIFICANCE OF CLUSTERS FOR INCREASING BUSINESS PERFORMANCE
}

\section{- Eva Stichhauerova, Miroslav Zirka, Natalie Pelloneova}

\begin{abstract}
This article focuses on the impact of clusters on performance in five selected industries. Focused on increasing the competitiveness of regions and enterprises, clusters are currently considered one of the most essential tools of industrial policy. This includes the Czech Republic, where cluster initiatives have been systematically supported since 2004 by operational programmes. The goal of this research was to determine whether cluster organizations have a positive effect on the performance of their member enterprises in various industries. Another goal was to verify the relation between the financial and innovative performance of the member enterprises. The research was carried out on a sample of five clusters in the automotive, IT, furnituremanufacturing, packaging and machinery industries, with Data Envelopment Analysis used for this performance evaluation. The enterprises were divided into three groups: companies that are members of cluster organizations, companies that are active in the same region and industry but are not members of a cluster group, and companies from the respective industry that operate outside the region of the given cluster. The results of the study indicate that in four industries (automotive, IT, packaging, machinery), member companies of cluster organizations achieve better results than non-members or firms active in other regions. On the other hand, it was not possible to prove a positive relation between company performance and their registered industrial rights, neither from the perspective of cluster membership nor their activity in the respective industry and region.
\end{abstract}

Keywords: competitiveness, cluster organization, technical performance, innovation performance, Data Envelopment Analysis

JEL Classification: D23, L25, L60

Received: March, 2020

1st Revision: June, 2020

Accepted: June, 2020

\section{INTRODUCTION}

The finding that the clustering of companies within a specific industry in a particular location brings entities positive externalities was first reported as far back as a century ago in the work of Marshall (1920). This premise was further developed in the 1990s by Michael Porter, who con- 
nected agglomeration theory with strategic management, thus creating the concept of an industry cluster. Porter (1998) defines a cluster as a "geographically proximate group of mutually interconnected companies and associated institutions in a particular field, linked by commonalities and complementarities." These entities compete with each other but also collaborate and mutually complement one another.

Clusters play an important role in modern industrial policies based on their support of competitiveness, strengthening framework conditions, fostering industry-specific approaches, as well as the support of public-private collaborations (Ketels, 2019). Clusters link all the basic "ingredients" of business - the availability of sources as well as goals of individuals - to achieve competitive success, while incorporating the ideas of proximity, networks and specialization. Clusters initiate and revitalize collaboration in business environments, and they stimulate competitive pressure, both among direct and even indirect competitors and non-competing members (Bialic-Davendra, 2011).

According to Kincaid (2005), clusters offer all involved members a whole array of benefits, particularly as reflected in effectiveness, productivity and innovation activities, thus contributing to increasing performance and competitiveness. Clusters create an environment friendly to innovation and know-how creation. For this reason, regions with strong clusters are considered to be leaders in the area of innovation, as globalization further advances this trend. Clusters should also have a positive effect on the financial performance of companies, as they are driven by benefits such as increased resource efficiency (lower prices) and flexibility (mobility of work force), as well as innovation. Companies in clusters benefit from the proximity of the other cluster members due to improvements in the flow of know-how, increasing the availability of qualified work forces, as well as unplanned interactions that are essential components of the innovation process (Spirková et al., 2015). Other publications, however, also include critical studies calling into question the positive effect of clusters on performance (Kukalis, 2010; Ruland, 2013).

The goal of this article is to identify whether cluster organizations in the Czech Republic in various industries have generally had a positive effect on the performance of the member companies or whether the putative positive effects of cluster organizations only appear in certain industries. This research also seeks to determine whether the financial performance of the member companies reflects their innovation performance as characterized by the registered results of technical creative work, industrial designs and rights to mark geographical indications and appellations of origin.

The structure of the article is divided into three parts. The first part of the article briefly outlines the approaches to measuring corporate performance. The second part introduces the research methodology, which is based on a comparison of three samples of enterprises in five industries (automotive, IT, furniture-manufacturing, packaging and machinery industries). The third part of this article covers research results and compares the results of the study with findings by other authors.

\section{THEORETICAL BACKGROUND}

If company performance is to be managed, it must be measured (Browne et al., 1997). Simple ratio indicators may be used to measure performance, along with sets of pyramid indicators, composite indicators, multivariate and multi-criteria methods (Žižka et al., 2016). 
Financial performance is frequently measured using various ratio indicators such as ROA, ROE, ROS, etc. (Dyer \& Reeves, 1995; Egerová \& Nosková, 2019; Leković et al., 2019). However, there is a growing interest in company performance indicators at present that are also based on nonfinancial indicators. This applies in particular to situations in which the financial information shows a positive trend (Coram et al., 2011). Modern approaches take into account the concept of wealth maximization and other non-financial aspects such as innovation (e.g. the number of new products developed in a certain time period, number of new patents), customer satisfaction, customer loyalty and employee motivation (Arlbjørn \& Haug, 2010). For example, the effect of innovation activities on business performance was demonstrated by Leković et al. (2019).

Most authors focus primarily on measuring financial performance. Innovation performance, another type of performance indicator, is rather overlooked in professional publications. Among those focused on it are Wu \& Lin (2011), according to which the most frequently used metrics of innovative capabilities of a company are innovation success rate, market share and innovation profit rate. Marr (2015) adds that also among the most key indicators of innovative performances is Innovation Pipeline Strength, i.e. a measurement of the potential future income from ongoing innovative projects. In the narrower sense, innovation performance relates to company outputs and is measured by the degree to which they introduce their inventions into the market (Hagedoorn \& Cloodt, 2003). This particular approach to innovation performance, a narrower one, was used in the research for this article.

The mono-criteria approach is unsuitable for measuring company performance reflective of various dimensions and pillars (e.g. financial and innovative). The results of comparing company performance on the basis of a single criteria are almost always contradictory, since by using more varied indicators broader results can be obtained. For this reason, more complex multi-criteria methods of performance measurement were developed, covering an entire range of inputs and outputs affecting business performance.

Among these multi-criteria methods, the concept of the Balanced Scorecard (BSC) is one that measures company performance based on four balanced perspectives: financial, customer, internal business processes and learning/growth. BSC supplements financial indicators regarding past performance with non-financial indicators and drivers of future company performance. The goals and indicators are based on both company vision and strategy. BSC is an alternative to traditional financial indicators that, in effect, measure the company's past performance. BSC is not merely a method of measuring company performance, but also a strategic planning and management system interconnecting business activities with the company's vision and strategy (Lesáková et al., 2017).

Also among multi-criteria methods used in this article is Data Envelopment Analysis (DEA), a method based on models of linear programming that deduce relative effectiveness or performance of the compared decision-making units (DMUs) on the basis of multidimensional inputs and outputs (Kocisova et al., 2018). Unlike in publications focused on performance, DEA does not strictly differentiate between terms such as performance and efficiency. It relies on the context of the mathematical quantity used. The DEA method was originally developed for evaluating the effectiveness of public organizations, such as schools or hospitals (Kocisova et al., 2018; Szabo et al., 2018). Further development showed that it was usable for the evaluation of business entities as well. 
For example, Düzakın \& Düzakın (2007) applied DEA to industrial companies in Turkey and proved that the evaluation of business performance depends on the branch. The number of highly performing companies was significantly lower when measured across industries than in applying the analysis to individual branches, which relates to the homogeneity of units examined. In his research, Žižka et al. (2018) came to the conclusion that the evaluation of performance of clustered companies depends on their branch.

It must be stressed that DEA measures relative technical efficiency, meaning that it identifies the best practice group of units within the respective evaluated set of all units. At the same time, DEA shows a degree of non-efficiency of the other units as well as necessary improvement in the inputs and outputs of these units (Yang, 2006). All permissible combinations of input and output form the group of production options. This is limited by an efficient frontier that identifies the highest level of outputs achievable with the given volume of inputs (Düzakın \& Düzak1n, 2007). The best units serve as a benchmark (Ruiz \& Sirvent, 2019).

There are a considerable number of versions of DEA models. Their description exceeds the possibilities of this article. The oldest CCR model with the presumption of constant revenues to scale (CRS) was covered by Charnes et al. (1978). In 1984, the method was generalized for the condition of variable returns to scale (VRS). This model is referred to as BCC (Banker et al., 1984). The BCC model, focusing on input, was used in the research covered by this article. It works with virtual inputs and virtual outputs, the scales of which are established using linear programming to maximize the efficiency of every unit.

The goal of this linear programming model is to maximize the objective function $z$ (1) within the limiting constraints (2), see e.g. Zhu (2014). Inputs $x j$ of units q have the weights $v j$ (number of inputs is $m$ ). Outputs $y i$ have the weights $u i$ (number of outputs is $r$ ). The variable $\mu$ indicates deviation from CRS. Efficient units have the objective function value of one. These units are located on the efficiency frontier. Inefficient units have the value $z$ lower than one.

$$
\begin{aligned}
& z=\sum_{i=1}^{r} u_{i} y_{i q}+\mu \\
& \sum_{i=1}^{r} u_{i} y_{i q}+\mu \leq \sum_{j=1}^{m} v_{j} x_{j q}, q=1,2, \ldots, n \\
& \sum_{j=1}^{m} v_{j} x_{j q}=1 \\
& u_{i} \geq \varepsilon, i=1,2, \ldots r ; \varepsilon \text { is very small non }- \text { Archimedean number }(>0) \\
& v_{j} \geq \varepsilon, j=1,2, \ldots, m \\
& \mu \in R
\end{aligned}
$$

As indicated in the beginning of this article, publications provide a large number of arguments supporting clusters. Clusters may form in multiple ways, such as naturally, meaning bottom-up on the basis of an initiative and actual needs of companies and institutions who intend to profit from the synergic effects of a cluster in the given region (Balog, 2016). A second approach is top-down, characterized by a cluster initiative of a specific organization, usually a governmental one. It is typical of such clusters to have their foundation and development financed from 
public funds. The goal of a cluster initiative is to support growth and competitiveness within the cluster and the region (Linqvist et al., 2013). A cluster organization is an independent legal entity (for example an association) formed as a result of such a cluster initiative.

The support of clusters is also a part of economic policy in the Czech Republic. The first Czech cluster - Moravian-Silesian Machine Industry Cluster - was founded based on the initiative of the CzechInvest agency in 2002. The largest boom of cluster foundations then took place in 2004, due to the approval of the Cluster sub-programme within the Operational Programme Industry and Enterprise. Upon the completion of this programme in 2006, the support of cluster development continued through other programmes as well as in subsequent programme periods. In the years 2007-2013, it was the Operational Programme Enterprise and Innovation, and from 2014 the Operational Programme Enterprise and Innovations for Competitiveness that are planned to continue through 2020. In total, 114 cluster organizations were formed in the Czech Republic in the years 2002-2018, of which 98 still exist (Pelloneová \& Žižka, 2019).

To the contrary, literature also offers studies pointing out that the positive effect of clusters on performance was not always proven. Among such studies is, for example, Kukalis (2010) who studied financial performance in the pharmaceutical and computer industry in relation to cluster memberships over an extended time period. The research conducted did not prove a positive effect of clusters on financial performance. Ruland (2013) came to a similar conclusion when comparing the profitability of companies in industry clusters and in non-member companies, and this also in relation to the size of the company. In case of small firms, it was even found that their profitability in clusters is significantly lower than in non-clustered companies. In the cases of large companies, no significant difference in performance was found in relation to cluster membership.

\section{RESEARCH OBJECTIVE, METHODOLOGY AND DATA}

The main objective of this article is to identify whether cluster organizations have a positive effect on the performance of their member companies. This performance is evaluated using a multi-criteria DEA. The reason for choosing the DEA method is the possibility to use a larger number of inputs and outputs (financial and non-financial) when evaluating the efficiency or performance of units. A partial goal is to discover whether the positive relationship between memberships in cluster organizations and performance is valid for all examined industries. Another subject of the research is the relation between performance and innovative activities of the companies.

The research included five industries: automotive, machinery, furniture-manufacturing, IT and packaging. These industries were selected with consideration to the length of existence of cluster organizations. The cluster organizations in these fields were founded in the 'first wave'. Therefore, these clusters are among the oldest ones in the Czech Republic.

The source of accounting data (balance sheet, profit and loss account) was the commercial database MagnusWeb (Bisnode, 2019). In case some accounting data was unavailable for a certain 
company, the non-existence of the accounting record was verified in the collection of documents of the commercial register and possibly supplemented. Data regarding the foundation of the company and number of employees was obtained from the Commercial Register's Collection of Documents. The number of patents, utility models, industrial designs, and trademarks were established using research in the databases of the Industrial Property Office (2019). All data is applied as of December 31, 2016. The largest number of financial records was also available for the year 2016.

The research process was divided into the following steps. This is the authors' own methodology which was tested in previous research (Žižka et al., 2018). For current research, however, it has been adopted in the area of examining the relationship between the DEA performance score and innovation performance score.

Step 1: Lists of companies within the five industries - a list of members - was prepared for each cluster organization. Data sources were the respective cluster websites. The created database contains: entity name, registration number, date of foundation, primary subject of activity according to the NACE classification, type (company, research institution, association, university), address and contact information. Due to the research focus on performance evaluation, only data regarding business entities - companies - was used. A core was established for each cluster (Table 1) - identifying the predominant type of member business activities according to the NACE statistical classification. It is necessary for the DEA method to be able to consider the units as homogenous.

In the next phase of the research, a second list of non-member companies active in the core industry, located in the region of operation of the cluster organization, was compiled. In the context of this article, these companies are understood as a natural cluster. The region of operation of the cluster organization is specifically defined by it; e.g. OMNIPACK Cluster operates in three Czech regions: Hradec Králové, Pardubice and Vysočina. Subsequently, the third list included companies that have the same primary subject of activity according to the NACE classification as companies in a cluster organization, but their seat is in other regions of the Czech Republic. Therefore, the research was divided into three samples $(\mathrm{C}$ - members of the cluster organizations, $\mathrm{N}$ - non-members of the cluster organizations within the given core industry and region, $\mathrm{O}$ - other companies in the given industry outside the regions).

Step 2: Data collection - accounting data was obtained from the MagnusWeb database (balance sheet, profit and loss account) and should it be unavailable, then from the collection of documents maintained by the commercial register. However, particularly in the case of small companies, accounting data is not available. The problem is that in the Czech Republic, a number of business corporations do not fulfil their legal obligation to publish their accounting statements. According to the analysis conducted by the Bisnode company (Bisode,2018), in 2016, 65\% of Czech companies failed to do so. 
Tab. 1 - Numbers of examined units. Source: own research

\begin{tabular}{|l|l|l|l|l|l|}
\hline $\begin{array}{l}\text { Cluster Organiza- } \\
\text { tion Name }\end{array}$ & $\begin{array}{l}\text { Core Indus- } \\
\text { try (NACE) }\end{array}$ & \multicolumn{5}{l}{ Number of Examined Companies / Total } \\
\hline & & C & N & O & Total \\
\hline $\begin{array}{l}\text { Moravian-Silesian } \\
\text { Automotive Clus- } \\
\text { ter c.a. }\end{array}$ & 293 & $11 / 11$ & $21 / 25$ & $106 / 135$ & $138 / 171$ \\
\hline IT Cluster c.a. & 620 & $8 / 8$ & $127 / 718$ & $343 / 3,409$ & $478 / 4,135$ \\
\hline $\begin{array}{l}\text { Cluster of Czech } \\
\text { Furniture Manu- } \\
\text { facturers }\end{array}$ & $161,162,310$ & $15 / 16$ & $10 / 13$ & $193 / 284$ & $218 / 313$ \\
\hline $\begin{array}{l}\text { OMNIPACK } \\
\text { Cluster (packag- } \\
\text { ing) }\end{array}$ & 172,222 & $12 / 16$ & $27 / 104$ & $257 / 764$ & $296 / 884$ \\
\hline $\begin{array}{l}\text { Czech Machinery } \\
\text { Cluster c.a. }\end{array}$ & $251,28 x$ & $9 / 10$ & $396 / 1,011$ & $360 / 1,836$ & $665 / 2,857$ \\
\hline Total & $55 / 61$ & $481 / 1,871$ & $1,259 / 6,428$ & $1,795 / 8,360$ \\
\hline
\end{tabular}

In the research conducted, the success rate of obtaining accounting data was between $10 \%$ and $100 \%$ (Table 1). For example, the very low ratio of information obtained in IT companies outside the cluster is due to the type of businesses - self-employed individual and micro-companies - in this field (contrary to the cluster organization that represents larger companies). The data regarding corporate innovation activities (patents, utility models, industrial designs, and trademarks) was obtained from the database of the Industrial Property Office. Data regarding currently active registered industrial rights were obtained for companies whose accounting records were available.

Step 3: The definition of inputs and outputs for the DEA model - three inputs were chosen, two of which are considered traditional factors of production: labour and capital. Specific indicators were number of employees, as well as long-term capital (a sum of equity, long-term obligations and bank loans). The third input was company history (as of December 31,2016), as a form of an accumulated intellectual capital of the company (knowledge and skills of employees gained during the company's existence). The revenue to cost ratio was selected as the output indicator, which can be considered as a basic measure of economic efficiency. The benefit of this indicator is that it is always non-negative (unlike the annual results, value added or economic value added), which is actually the condition for using the DEA model.

The model evaluates company performance on the basis of three inputs and one output (Figure 1). The BCC model, with the presumption of variable revenues to scale and oriented toward inputs, was used because increasing or decreasing revenues to scale in these industries were identified by previous studies (Žižka et al., 2016). This means that we assume that the companies will decrease upon the given output, orienting toward the decrease of inputs. The BCC mathematical mode was described in the previous chapter. MaxDEA Ultra Pro software was used for the numeric calculations of performance scores. 
Step 4: Establishing performance scores: a performance score was established for each company in all industries and data sets using the DEA model solution. The ratio of companies on the efficiency frontiers was established for each set, along with the median performance score. The analysis was executed per industry as well as subsequently for all industries combined.

Step 5: Comparison of the performance scores between groups of companies: the Kruskal-Wallis test was used to identify the differences between the $\mathrm{C} / \mathrm{N} / \mathrm{O}$ groups within each industry. This is a non-parametric variant of the variance analysis, testing differences between the medians of performance scores. We test the null hypothesis about the equality of the median values of the compared groups, as opposed to the alternative hypothesis, which states that the null hypothesis does not apply. The mean differences of the individual groups were then further examined using the Games-Howell post-hoc test. This is a non-parametric approach to comparing multiple group observations that works with the sequences of the original values. Its benefit lies in not requiring the fulfilment of conditions of normal distribution, homogeneity of the variance, nor of the same group size. The null hypothesis states that there is no difference between the means of the compared groups, the alternative analysis states the opposite. The test results were evaluated by the P-value approach. P-value - or statistical significance - is the probability with which, assuming the null hypothesis is true, we could obtain data that contradicts the null hypothesis as much or even more than the data we observe (Dahiru, 2008). All tests were performed to the significance level alpha 5\% using statistical software STATGRAPHICS XVIII. If the calculated P-value of the performed test was less than 0.05 , the null hypothesis was rejected and the validity of the alternative hypothesis was accepted.

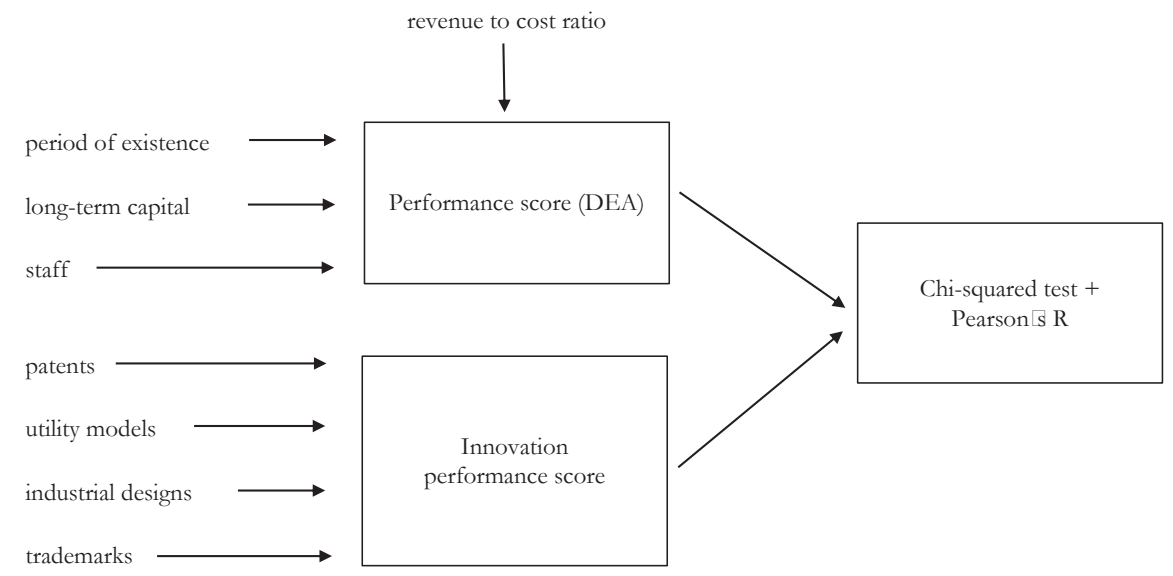

Fig. 1 - Research concept. Source: own research

Step 6: The classification of companies into two groups - innovative and non-innovative. Companies that have at least one result of the industrial rights type are considered innovative. The innovation activity of a company in this research was evaluated in a simplified manner, due to the low number of registered rights to industrial property and is primarily expressed by the binary variable with the values 0 or 1 . In case the company had no registered industrial rights, the variable value was 0 . In case the company had obtained rights to industrial property, this variable value became 1 . 
Step 7: Examining the relationship between performance and the innovation activity of the companies - the performance was measured using the performance score resulting from solving the DEA models separately within the five industries and partial groups $\mathrm{C} / \mathrm{N} / \mathrm{O}$. The performance score value was transposed to a variable with the binary value of 0 or 1 . The value 1 was assigned to companies that were identified as efficient units within the group, meaning those with best practices. Other companies with the performance score lower than 1 obtained the value 0 . The relation between whether the company has registered results of innovative activities and whether it has been identified as a high-performance unit was examined using the Chi-square test of independence for categorical variables. The null hypothesis was formulated in such a way that no relation exists in the population between whether the company has registered results of innovative activities and whether it has been identified as a high-performance unit. The alternative hypothesis states the opposite. The degree of dependence was measured using the Pearson's $\mathrm{R}$ correlation coefficient.

\section{RESULTS AND DISCUSSION}

Tab. 2 shows median performance scores in the individual industries and groups of companies. Based on the performed Kruskal-Wallis test, it can be concluded that statistically significant ( $\mathrm{p}$-value $<0.05$ ) differences between the $\mathrm{C} / \mathrm{N} / \mathrm{O}$ groups of companies were identified in case of four industries: automotive, furniture manufacturing, packaging and machinery. In case of the IT industry, the Kruskal-Wallis test at the 5\% significance level did not identify differences between all groups $\mathrm{C} / \mathrm{N} / \mathrm{O}(\mathrm{p}$-value $=0.12)$.

The differences between the $\mathrm{C} / \mathrm{N} / \mathrm{O}$ groups of companies were further examined by the posthoc analysis using the Games-Howell test. The automotive, furniture and packaging industries showed statistically significant differences $(\mathrm{p}$-value $<0.05)$ in the performance score between all the $\mathrm{C} / \mathrm{N} / \mathrm{O}$ groups mutually. The highest median performance score was reached in the automotive and packaging industry, in groups with cluster organizations. This means that in these industries, companies organized in institutionalized clusters reached higher levels of performance. In the case of the furniture-manufacturing industry, the median performance score was highest in the region where the cluster is active, however, this in non-cluster companies. Nevertheless, a positive influence of the cluster on performance may be assumed even here. The lowest performance scores in the above-mentioned three industries were reached outside the region of the cluster organization province.

In the machinery industry, the post hoc Games-Howell test demonstrated a significant difference between the performance scores of cluster-organization member companies as opposed to the other two remaining groups $\mathrm{N}$ and $\mathrm{O}$. A similar result was identified in the IT industry where a significantly different performance score was found in the group of cluster-organization member companies compared with the remaining two groups. To the contrary, the performance score between non-member companies and other companies outside the region may not be considered different - this finding is true both for the machinery industry and the IT industry. 
Tab. 2 - Performance score medians. Source: own research

\begin{tabular}{|l|l|l|l|}
\hline Industry & \multicolumn{3}{|l|}{ Group of Companies } \\
\hline & $\mathrm{C}$ & $\mathrm{N}$ & $\mathrm{O}$ \\
\hline Automotive & 0.938 & 0.501 & 0.063 \\
\hline IT & 1.000 & 0.500 & 0.500 \\
\hline Furniture & 0.846 & 0.986 & 0.442 \\
\hline Packaging & 1.000 & 0.338 & 0.115 \\
\hline Machinery & 0.804 & 0.080 & 0.077 \\
\hline
\end{tabular}

The following Table 3 indicates the ratios of companies that are located on the efficiency frontier and represent the benchmark for other companies within their industry.

The number of units with the best performance upon the application of DEA on the partial groups $\mathrm{C} / \mathrm{N} / \mathrm{O}$ in the individual industries was 372 (of 1,795), meaning approx. 21\% (Table 4). The highest occurrence of best practices was in the group with cluster organizations with the exception of the furniture-manufacturing industry.

Table 4 shows the differences between the numbers of high-performance units in relation to the method of defining the DMUs set. It may be concluded that upon defining the DMUs set as one group $\mathrm{C} / \mathrm{N} / \mathrm{O}$ within an industry, a higher number of high-performance companies was found in every industry $(21 \%)$ than when the DMUs set was only composed of companies from the industry regardless of them belonging to a particular group (18\%). Similarly, it may be observed that upon defining the DMUs set as a set of companies operating within an industry, a higher number of high-performing units was identified (18\%) than when the DEA was applied to a set of all evaluated industrial companies (4\%).

Tab. 3 - Ratios of best-practice units. Source: own research

\begin{tabular}{|l|l|l|l|l|}
\hline \multirow{2}{*}{ Industry } & \multicolumn{2}{|l|}{$\begin{array}{l}\text { The Ratio of Best-Practice } \\
\text { Units to the Total Number of } \\
\text { Units in the Group }\end{array}$} & $\begin{array}{l}\text { The number of Efficient } \\
\text { Units in the Industry in All } \\
\text { Groups C+N+O }\end{array}$ \\
\hline & $\mathrm{C}$ & $\mathrm{N}$ & $\mathrm{O}$ & \\
\hline Automotive & $45 \%$ & $33 \%$ & $11 \%$ & 24 \\
\hline IT & $75 \%$ & $45 \%$ & $47 \%$ & 224 \\
\hline Furniture & $40 \%$ & $50 \%$ & $4 \%$ & 18 \\
\hline Packaging & $58 \%$ & $22 \%$ & $10 \%$ & 39 \\
\hline Machinery & $44 \%$ & $11 \%$ & $9 \%$ & 67 \\
\hline Total & $51 \%$ & $22 \%$ & $19 \%$ & 372 \\
\hline
\end{tabular}

DEA thus proves its characteristic need for evaluation of homogeneous DMUs. The results obtained are in accord with the conclusions made by Düzakın \& Düzak1n (2007) that the ratios of best-practice companies are higher in more specifically defined industries than when compared with a broadly defined industry. 
The very high ratio of high-performance companies in the IT industry is likely caused by the high ratio of companies $(42 \%)$ with only one employee and similar history in this industry. The entry characteristics of these micro-companies are thus very similar.

The Chi-square test of the independence of categorical data was performed in order to verify the existence of the relation between the company having registered industrial property rights and the fact that it was identified as a high-performance unit.

Tab. 4 - The number of efficient units according to the definition of the DMUs set. Source: own research

\begin{tabular}{|l|l|l|l|}
\hline \multirow{2}{*}{ Industry } & \multicolumn{2}{|l|}{ Numbers of Best-Practice Units within } \\
\cline { 2 - 4 } & Groups of the Given Industry & Industry Field & Entire \\
\hline Automotive & 24 & 13 & 6 \\
\hline IT & 224 & 216 & 39 \\
\hline Furniture & 18 & 7 & 3 \\
\hline Packaging & 39 & 28 & 5 \\
\hline Machinery & 67 & 63 & 18 \\
\hline Total & 372 & 327 & 71 \\
\hline
\end{tabular}

This correlation was proven by tests in five groups in three industries: packaging, machinery and IT (Table 5). However, the identified dependence between the variables performance and innovation activity is indirect and, with the exception of one case (companies in cluster organizations in the packaging industry), weaker. This means that the best-practice companies do not have registered results of innovation activities that would be included in the category of industrial rights. However, this does not automatically mean that clustered companies do not put effort into innovation activities.

According to the CZSO (2018a) analysis, over a half of Czech companies in the manufacturing industry show innovative activities. However, approximately a third of the innovations have the character of non-technical innovations (organizational and marketing) and, in the case of technical innovations (products and processes), the predominant methods of protecting industrial ownership are by use of the trade secret. This means that the significant majority of the results of innovation activities are not registered in the databases of the Industrial Property Office.

Tab. 5 - Chi-square test of categorical data. Source: own research

\begin{tabular}{|l|l|l|l|}
\hline \multirow{2}{*}{ Industry } & \multicolumn{4}{|l|}{ P-value (Pearson's R) } & O \\
\cline { 2 - 4 } & $\mathrm{C}$ & $\mathrm{N}$ & 0.1513 \\
\hline Automotive & 0.3383 & 0.4687 & $<0.0000^{*}(-0.2594)$ \\
\hline IT & 0.3458 & 0.2409 & 0.2384 \\
\hline Furniture & 0.2918 & 0.2918 & $0.0047 *(-0.1763)$ \\
\hline Packaging & $0.0034 *(-0.8452)$ & 0.0715 & $0.0186^{*}(-0.1240)$ \\
\hline Machinery & 0.0989 & $0.0190^{*}(-0.1363)$ & \\
\hline
\end{tabular}

*statistically significant at $\mathrm{p}=.05$ 
From the perspective of comparing the results of this research to other authors, we can conclude that, in essence, this research confirmed the prevailing opinion regarding the positive effect of clusters on performance (Lee \& Hsu, 2012; Porter, 1998; Spirková et al., 2015).

However, there are certain differences regarding the relation to the type of the cluster (cluster organization versus natural cluster). The cluster organization members group showed the highest performance in four industries out of the five included in the research (the exception was furniture manufacturing). The group of non-member companies active within the region covered by a cluster (where the existence of a natural cluster could also be expected) indicated a positive effect of localization on performance (compared with other companies outside of the regions) in the cases of three industries. In the case of the IT and machinery industries, the positive effect of natural industry concentration on performance was not automatically confirmed.

In the case of the IT industry, the reason may lie in the size structure of companies outside the cluster organization. As found by Ruland (2013), the profitability of small companies in clusters was worse than among similar companies outside the cluster. Nonetheless, it is noteworthy that Ruland (2013) did not differentiate between cluster organizations and natural clusters.

In all the industries covered by our research, the groups of member companies in cluster organizations had the largest median value of number of employees. (Note: this is also true for the average values of number of employees, a figure that is, nonetheless, affected by large numbers of employees in only a few companies, thus medians were used for comparison). Specifically, in the IT industry, the median in the cluster organization group is 129 employees. Outside the group of cluster organization members, the majority of companies are microenterprises (the median in group $\mathrm{N}$ is 3 ; in group $\mathrm{O}$ only 2). Thus, the companies active in the IT industry outside the cluster organizations are primarily microenterprises, in which the effect of cluster membership on performance is apparently negligible.

However, a different situation can be found with the machinery industry, in which the group of cluster organization members also has the highest median (133 employees). In the other two groups, the medians are also lower $(\mathrm{N}-26$ and $\mathrm{O}-27)$. Yet in comparison with the IT industry, it cannot be concluded that the industry is represented by a majority of microenterprises. The number of employees in a company is evidently only one among a number of factors affecting the success rate of clustering.

The furniture manufacturing industry showed a similar size structure to the IT industry. Paradoxically, the companies achieving the best performance in furniture manufacturing were not members of cluster organizations. Yet, their median number of employees is as low as that of the IT industry (3 employees). On the other hand, the number of employee median in cluster organizations was 66.

In this regard, we must point out the findings of Skokan \& Zotyková (2014) indicating that a cluster organization may also be composed of several sub-clusters. Skokan \& Zotyková (2014) demonstrated this finding using the same machinery cluster that was one of the subjects of our research. The first sub-cluster is composed of a larger number of enterprises that do not affect the performance of the whole cluster organization in a significant manner. The second sub-cluster includes several companies with a more significant effect on the overall results of the cluster organization. The third sub-cluster is composed of a single large dominant company. 
The internal structure of the member base was, therefore, another factor affecting cluster performance. From this perspective, the cluster organizations in the IT and machinery industries show a certain similarity, i.e. in both cluster organizations a single company dominates. In this firm the number of employees exceeds the average numbers of employees in the cluster organization companies approximately five-fold. In the furniture manufacturing industry, there is also one dominant firm in the non-members group in the region covered by the cluster. At the same time, all these dominant companies showed performance scores higher or equal to the median in the given group.

Lee \& Hsu (2012) concluded that the stronger a cluster becomes in a region, the larger the effect on the performance of its member organizations. The investigators measured the strength of a cluster using a location quotient which became the standard for measuring regional industry specialization. The data regarding employment obtained from the register of economic entities (CZSO, 2018b) was used in our study to establish the LQ., with a LQ significantly higher than one found in all researched industries in the regions covered by the cluster organizations. The LQ was strongest in the machinery industry (4.94), and lowest in the furniture manufacturing industry (1.96). The broader geographic dispersion of the furniture manufacturing industry could thus explain the lower effect of the cluster on company performance.

The negative finding regarding the relationship between company performance and selected innovation activities could be explained by the fact that only registered industrial rights were studied. We can thus concur with the opinion of Freeman \& Soete (1997) that patents may be a measure of invention but not of innovation success. Not all ideas are patented or protected in a similar manner, and patents also bring varied economic impacts (Baptista \& Swan, 1998). Despite this, patents are frequently used in publications, as are the measure of innovative outputs (Acs et al., 2002) since obtaining other indicators is very difficult.

Thus, the results of our research can only be interpreted in the sense that the protection of industrial rights has no immediate relation to company performance. Yet, as found by Foege et al. (2017) using a large sample of German production companies, the formal protection of intellectual property is meaningful for companies protecting against imitation triggered by a partnership. This finding represents a challenge for further research of innovative activities of companies organized in clusters. Clusters may increase trust among partners and thus decrease barriers of innovative partnerships.

\section{CONCLUSIONS}

The goal of this article was to identify whether cluster organizations in the Czech Republic have generally had a positive effect on the performance of the member companies. It may be concluded on the basis of the research that clustered companies reach higher performance scores than other companies. This correlation was found in all five industries examined, while in four of these industries the performance score was highest in the companies that are members of cluster organizations. Only in the furniture-manufacturing industry was the highest performance score within the group of companies that were not members of a cluster within the province of the Cluster of Czech Furniture Manufacturers. 
However, even in this industry it remains valid that the mean performance score of companies within a cluster organization is higher than in companies active outside the cluster region. Along with the furniture-manufacturing industry, the higher performance score of the non-member companies within the cluster region compared to companies from other regions was shown in the automotive and packaging industries. On the contrary, in cases of the IT and machining industry, no significant difference was found in the performance of non-member companies in the region of the cluster province as opposed to companies from other regions. It may be assumed based on these results that cluster initiatives or the natural clustering of companies may not have an equally strong effect on improving company performance.

In essence, our research confirmed the previous finding that clusters may or may not have a positive effect on company performance. The specific contribution of this research is the identification of industries in which the foundation of a cluster organization likely contributed to performance improvement in the member companies (automotive, IT, packaging, machinery) and in which this effect was not evident (furniture-manufacturing).

Simultaneously, the reasons the effect of clusters in some industries is lower are discussed. Among these reasons are the varying size structure of companies, different inclusion rates of dominant companies in the cluster, as well as the varying significance of the industry for the specialization of the region. Additionally, another important factor is the actual functioning of the cluster organization and intensity of member collaboration within the cluster, which represents a factor that is difficult to identify and quantify. Despite this, actual functioning may explain the fact that in some industries cluster organizations work better and have a larger impact on the performance of their member companies.

In terms of the additional partial goal, it was not possible to prove a positive relation between performance and innovative activities of a company. This was true in all the industries and all groups, clustered or otherwise. The reason for this is likely the fact that registered results of technical innovative activities form only a part of the overall innovative activities.

The authors are aware of several limits of this research. In general, the availability of company accounting data for evaluation is a large problem. This is particularly true in industries and clusters with a large proportion of self-employed persons or micro-companies. A further limit is the considered relation between higher performance and the existence of a cluster organization. It is very difficult to differentiate a realistic specific positive effect of the existence of a cluster organization from other factors. The considered relation between performance and clusters may only be verified indirectly through the examination of various industries.

Certain limitations are also related to the statistical data processing methods used. In addition to the advantages already mentioned, the use of non-parametric statistical tests also creates certain disadvantages in comparison with parametric tests: they may have a lower statistical power; the information contained in the data is not fully used since the original values are often replaced by their order; their application to large samples is complex; the number of existing analytical methods is smaller; and the information obtained is limited and more difficult to interpret (Nahm, 2016). 
Based on our research, the following recommendations can be formulated for companies: it only makes sense to join a cluster organization that engages in real activities in areas such as collaborative research, sharing research infrastructure, joint purchasing of resources, or shared promotion of industry products.

Acknowledgements

This study was supported by grant No. GA18-01144S "An Empirical Study of the Existence of Clusters and Their Effect on the Performance of Member Enterprises" of the Czech Science Foundation.

\section{References}

1. Acs, Z. J., Anselin, L., \& Varga, A. (2002). Patents and innovation counts as measures of regional production of new knowledge. Research Policy, 31 (7), 1069-1085. https://doi.org/10/ dt627p

2. Arlbjørn, A., \& Haug, A. (2010). Business Process Optimization. Aarhus: Academica.

3. Baptista, R., \& Swann, P. (1998). Do firms in clusters innovate more? Research Policy, 27 (5), 525-540. https://doi.org/10/d42wn4

4. Balog, M. (2016). Development Factors of Cluster Organizations in the Slovak Republic. Ekonomické ćasopis, 64 (2), 149-168.

5. Banker, R. D., Charnes, A., \& Cooper, W. W. (1984). Some Models for Estimating Technical and Scale Inefficiencies in Data Envelopment Analysis. Management Science, 30 (9), 1078-1092.

6. Bialic-Davendra Magdalena. (2011). An Investigation of a new Concept of WorldClass Clusters in Europe - A Case Study of the Visegrad Group of Countries. Journal of Competitiveness, 3 (2), 43-57.

7. Bisnode. (2018). Informační ne-povinnost. Prague: Bisnode Česká republika. Retrieved April 14, 2009, from https://www.bisnode.cz/o-bisnode/o-nas/novinky/informacni-ne-povinnost

8. Bisnode. (2019). MagnusWeb CZ Database. Prague: Bisnode Česká republika. Retrieved June 26, 2019, from https://magnusweb.bisnode.cz

9. Browne, J., Devlin, J., Rolstadas, A., \& Andersen, B. (1997). Performance Measurement: The ENAPS Approach. International Journal of Business Transformation, 1 (2), 73-84.

10. Charnes, A., Cooper, W. W., \& Rhodes, E. (1978). Measuring the Efficiency of Decision Making Units. European Journal of Operational Research, 153 (2), 429-444.

11. Coram, P. J., Mock, T. J., \& Monroe, G. S. (2011). Financial analysts' evaluation of enhanced disclosure of non-financial performance indicators. The British Accounting Review, 43 (2), 87-101. https://doi.org/10.1016/j.bar.2011.02.001

12. CZSO. (2018a). Inovační aktivity podniků 2014-2016. Prague: Czech Statistical Office. Retrieved December, 14, 2019, from https://www.czso.cz/csu/czso/inovacni-aktivitypodniku-2014-2016

13. CZSO. (2018b). Počet zaměstnanců podle okresů a podle CZ-NACE k 31. 5. 2018. Prague: Czech Statistical Office.

14. Dahiru, T. (2008). P - value, a true test of statistical significance? A cautionary note. Annals of Ibadan Postgraduate Medicine, 6 (1), 21-26. https://doi.org/10.4314/aipm.v6i1.64038 
15. Düzakın, E., \& Düzakın, H. (2007). Measuring the Performance of Manufacturing Firms with Super Slacks based Model of Data Envelopment Analysis: An Application of 500 Major Industrial Enterprises in Turkey. European Journal of Operational Research, 182 (3), 1412-1432. https://doi.org/10.1016/j.ejor.2006.09.036

16. Dyer, L., \& Reeves, T. (1995). Human Resource Strategies and Firm Performance: What do we know and where do we need to go? The International Journal of Human Resource Management, 6 (3), 656-670. https://doi.org/10.1080/09585199500000041

17. Egerová, D., \& Nosková, M. (2019). Top Management Team Composition and Financial Performance: Examining the Role of Gender Diversity. E\&M Ekonomie a Management, 22 (2), 129-143. https://doi.org/10.15240/tul/001/2019-2-009

18. Foege, J. N., Piening, E. P., \& Salge, T. O. (2017). Don't get caught on the wrong foot: A resorce based perspective on imitation threats in innovation partnerships. International Journal of Innovation Management, 21 (03), 1750023. https://doi.org/10/ggh2wc

19. Freeman, C., \& Soete, L. (1997). The economics of industrial innovation (3rd ed). MIT Press.

20. Hagedoorn, J., \& Cloodt, M. (2003). Measuring Innovative Performance: Is there an Advantage in Using Multiple Indicators? Research Policy, 32 (8), 1365-1379. https://doi. org/10.1016/S0048-7333(02)00137-3

21. Industrial Property Office. (2019). Online IPR Databases. Prague: Industrial Property Office. Retrieved January, 24. https://www.upv.cz/en/client-services/online-databases.html

22. Ketels, Ch. (2019). Towards a European Industrial Strategy: What Role for Clusters? Presented at the 22nd Global TCI Conference Strategic Clusters for Sustainable Growth: New Trends and Practices, Antwerpen. ttps://www.slideshare.net/TCINetwork/keynote-tci2019christian-ketels-towards-a-new-european-industrial-policy-what-role-for-clusters

23. Kincaid, B. L. (2005). Competitive Advantage of Clusters within Lesser Developed Countries of the South Pacific: An empirical Case Study Extending the Porter Diamond Model (Fiji, Papua New Guinea, Tonga). Ann Arbor: Capella University, ProQuest Dissertations Publishing.

24. Kocisova, K., Hass-Symotiuk, M., \& Kludacz-Alessandri, M. (2018). Use of the DEA Method to Verify the Performance Model for Hospitals. E\&M Ekonomie a Management, 21 (4), 125-140. https://doi.org/10.15240/tul/001/2018-4-009

25. Kukalis, S. (2010). Agglomeration Economies and Firm Performance: The Case of Industry Clusters. Journal of Management, 36 (2), 453-481. https://doi.org/10/b46w5p

26. Lee, Y. C., \& Hsu, H. (2012). Industry cluster research and analysis of the impact on business performance: With Reference to the solar power industry. ICSSSM12, 658-662. https://doi. org/10/ggigvc

27. Leković, B., Strugar Jelača, M., \& Marić, S. (2019). Importance of Innovative Management Practice: Solution for Challenges in Business Environment and Organization Performance. E\&M Ekonomie a Management, 22 (4), 68-84. https://doi.org/10.15240/tul/001/2019-4-005

28. Lesáková, L., Dubcová, K., \& Gundová, P. (2017). The knowledge and use of the Balanced Scorecard method in businesses in the Slovak republic. E\&M Ekonomie a Management, 20 (4), 49-58. https://doi.org/10.15240/tul/001/2017-4-004 
29. Lindqvist, G., Ketels, C., \& Sölvell, Ö. (2013). The Cluster Initiative Greenbook 2.0. Stockholm: Ivory Tower Publishers. Retrieved December 5, 2019, http://www. clusterobservatory.eu/system/modules/com.gridnine.opencms.modules.eco/providers/getpdf. jsp?uid=c57a2f9f-aa59-4af8-a8f9-4fa99e95b355

30. Marr, B. (2015). Key Performance Indicators For Dummies. West Sussex: For Dummies.

31. Marshall, A. (1920). Principles of Economics (8th ed.). Basingstoke: Palgrave Macmillan.

32. Nahm, F. S. (2016). Nonparametric statistical tests for the continuous data: the basic concept and the practical use. Korean Journal of Anesthesiology, 69 (1), 8-14. https://doi.org/10.4097/ kjae.2016.69.1.8

33. Pelloneová, N., \& Žižka, M. (2019). Sources of Financing of Cluster Organizations in the Czech Republic. Conference Proceedings from International Scientific Conference "The Poprad Economic and Management Forum 2019: Current Trends and Challenges in Businesses Management”, 30-41. Retrieved from http://www.manazmentpp.sk/wp-content/ uploads/2019/10/PEMF_2019_Proceedings.pdf

34. Porter, M. E. (1998). Clusters and the New Economics of Competition. Harvard Business Review, 76 (6), 77-90.

35. Ruiz, J. L., \& Sirvent, I. (2019). Performance Evaluation through DEA Benchmarking Adjusted to Goals. Omega, 87, 150-157. https://doi.org/10.1016/j.omega.2018.08.014

36. Ruland, W. (2013). Does Cluster Membership Enhance Financial Performance? IBusiness, 5 (1), 1-11. https://doi.org/10/gftigd

37. Skokan, K., \& Zotyková, L. (2014). Evaluation of Business Cluster Performance During Its Lifecycle. Acta Universitatis Agriculturae et Silviculturae Mendelianae Brunensis, 62 (6), 1395-1405. https://doi.org/10/ggh2t9

38. Spirkova, D., Caganova, D., \& Sujanova, J. (2014). Cluster Policy and its Influence on Economic Competitiveness. Applied Mechanics and Materials, 718, 16-21. https://doi.org/10/ $\operatorname{ggd} 8 \mathrm{mq}$

39. Szabo, S., Mihalčová, B., Gallo, P., \& Ivaničková, M. (2018). Evaluating Efficiency in Specialized Hospital Facilities: Developing the Model by Way of the Discriminant Analysis. E\&M Ekonomie a Management, 21 (3), 88-106. https://doi.org/10.15240/tul/001/2018-3-006

40. Wu, S., \& Lin, C. (2011). The Influence of Innovation Strategy and Organizational Innovation on Innovation Quality and Performance. International Journal of Organizational Innovation, 3 (4), $45-81$.

41. Yang, Z. (2006). A Two-Stage DEA Model to Evaluate the Overall Performance of Canadian Life and Health Insurance Companies. Mathematical and Computer Modelling, 43 (7-8), 910-919. https://doi.org/10.1016/j.mcm.2005.12.011

42. Zhu, J. (2014). Quantitative Models for Performance Evaluation and Benchmarking. Switzerland: Springer International Publishing.

43. Žižka, M., Valentová, V. H., Pelloneová, N., \& Štichhauerová, E. (2018). The Effect of Clusters on the Innovation Performance of Enterprises: Traditional vs New Industries. Entrepreneurship and Sustainability Issues, 5(4), 780-794. https://doi.org/10.9770/jesi.2018.5.4(6) 
44. Žižka, M., Valentová, V. H., \& Turčok, L. (2016). Performance Evaluation of Czech Innovative Companies: Data Envelopment Analysis Approach. International Journal of Strategic Property Management, 20 (4), 427-438. https://doi.org/10.3846/1648715X.2016.1239592

\section{Contact Information}

Ing. Eva Stichbauerova, Ph.D.

Technical University of Liberec

Faculty of Economics

Department of Business Administration and Management

Czech Republic

E-mail: eva.stichhauerova@tul.cz.

ORCID: 0000-0001-7201-678X

prof. Ing. Miroslav Ziøka, Ph.D.

Technical University of Liberec

Faculty of Economics

Department of Business Administration and Management

Czech Republic

E-mail:miroslav.zizka@tul.cz.

ORCID: 0000-0002-7804-3954

Ing. Natalie Pelloneova

Technical University of Liberec

Faculty of Economics

Department of Business Administration and Management

Czech Republic

E-mail:natalie.pelloneova@tul.cz.

ORCID: 0000-0003-3566-0677 